\title{
STRATEGI PEMBELAJARAN BERBASIS MASALAH DALAM PAI SEBAGAI UPAYA MENCEGAH PERKELAHIAN SISWA
}

\author{
Moh Eko Nasrulloh \\ Fakultas Agama Islam Universitas Islam Malang \\ e-mail: eko.nasrulloh@unisma.ac.id
}

Diterima: 07 Oktober 2019 | Direvisi: 29 April 2020| Disetujui: 22 Mei 2020

(C) 2018 Program Studi Pendidikan Agama Islam Fakultas Agama Islam Universitas Islam Malang

\begin{abstract}
Various problems related to SMP students still occur in the East Java region. Among these problems is the brawl between students. Teachers are instrumental in preventing juvenile delinquency. In choosing forward learning materials related to the values of peace and positive attitudes of students. The learning strategies used by teachers in those processes can use problem-based learning strategies. Research discussion with the type of library research or research library related to problem-based learning strategy. In research studies and analysis of content on documents and books and scientific works. One way to be aware and prevent students from negative behaviors by drafting a problem-based learning strategy. With the use of problem-based learning strategies students can understand the role that can be taken when there are problems. The result of learning from a problem-based learning strategy students can realize what the cause of the fight and what the must is doing to prevent the fight.
\end{abstract}

Keywords: Strategy, Problem-Based Learning, Fights

\begin{abstract}
Abstrak
Berbagai permasalahan terkait pelajar SMP masih terjadi di wilayah jawa timur. Diantara permasalahan tersebut yaitu tawuran antar pelajar. Guru berperan penting dalam mencegah terjadinya kenakalan remaja. Dalam memilih materi pembelajaran dikedepankan yang berkaitan dengan nilai-nilai perdamaian dan sikap positif siswa. Strategi pembelajaran yang digunakan oleh guru dalam proses tersebut dapat menggunakan strategi pembelajaran berbasis masalah. Pembahasan penelitian dengan jenis library research atau penelitian pustaka terkait objek strategi pembelajaran berbasis masalah. Dalam penelitian dilakukan kajian dan analisis isi terhadap dokumen maupun buku serta karya ilmiah. salah satu cara untuk menyadarkan dan mencegah siswa dari perilaku negatif dengan menyusun strategi pembelajaran berbasis masalah. Dengan penggunaan strategi pembelajaran berbasis masalah siswa dapat memahami peran yang bisa diambil ketika terjadi permasalaha. Hasil belajar dari strategi pembelajaran berbasis masalah siswa dapat menyadari
\end{abstract}


apa yang menjadi sebab terjadinya perkelahian dan apa yang ahrus dilakukan siswa untuk mencegah tejadinya perkelahian.

Kata Kunci: Strategi, Pembelajaran Berbasis Masalah, PAI, Perkelahian

\section{Pendahuluan}

Berbagai permasalahan terkait pelajar SMP masih terjadi di wilayah jawa timur. Diantara permasalahan tersebut yaitu tawuran antar pelajar. Tawuran pelajar antar sekolah sering terjadi disamping antar pelajar satu sekolah. Faktor yang menjadi sebab terjadinya tawuran juga beragam mulai dari tersinggung ucapan sampai masalah kriminalitas lainnya. Kejadian tawuran terjadi di daerah situbondo yang mengakibatkan meninggal dunia saeorang pelajar (Izi Hartono, jatim.tribunnews.com: 2019)

Dalam upaya untuk menangani permasalahan tersebut berbagai pihak melakukan peran masing-masing. Mulai dari kepolisian yang melakukan razia anak sekolah pada jam pelajaran sampai diperketat kegiatan siswa disekolah. Kerjasama antara kepolisian dengan pihak sekolah dalam sosialisasi narkoba dan kenakalan remaja di berbagai sekolah dilakukan. Berbagai aspek yang terkait dengan kenakalan remaja berupaya di carikan solusi untuk mengurangi kenakalan remaja.

Guru berperan penting dalam mencegah terjadinya kenakalan remaja. Pelajar diberikan pemahaman tentang bahaya dari kenakalan remaja. Kerugian yang diakibatkan dari adanya kenakalan remaja menjadi wawasan penting bagi siswa. siswa juga perlu arahan untuk melakukan hal-hal positif dibandingkan mencari kegiatan yang sia-sia.

Dalam pembelajaran guru memilih materi dan metode serta strategi pembelajaran untuk diberikan kepada siswa sesuai dengan kebutuhan dan tujuan pembelajaran. (Nurdin \& Usman, 2002) dalam Zulkifli, Nadjamuddin Royes, (2017, 120) Dalam memilih materi pembelajaran dikedepankan yang berkaitan dengan nilai-nilai perdamaian dan sikap positif siswa. metode pembelajaran yang berkaitan dengan materi perlu dipertimbangkan untuk lebih mengandung nilai-nilai resolusi konflik. Guru juga diharapkan menggunakan strategi yang tepat untuk menjalankan proses pembelajaran terkait nilai-nilai.

Strategi pembelajaran yang digunakan oleh guru dalam proses tersebut dapat menggunakan strategi pembelajaran berbasis masalah. Siswa dihadapkan dengan permasalahan-permasalahan yang biasa terjadi pada mereka. Mereka perlu membahas permasalahan remaja untuk diajak berpikir atas peristiwa-peristiwa yang negatif disekitarnya. Siswa juga diberikan perbandingan dengan peristiwa-peristiwa positif yang lebih 
produktif. Alasan melakukan hal-hal positif juga diperlukan siswa untuk dipertimbangkan. Semua itu diintegrasikan dalam proses pembelajaran berbasis masalah.

\section{Metode}

Pembahasan penelitian dengan jenis library research atau penelitian pustaka terkait objek strategi pembelajaran berbasis masalah. Dalam penelitian dilakukan kajian dan analisis isi terhadap dokumen maupun buku serta karya ilmiah. Analisis isi dilakukan dengan cara pemilahan tersendiri terhadap gagasan, pernyataan dan kalimat dalam dokumen. Dalam membahas hasil dilakukan observasi terkait tema dengan melihat buku-buku dan jurnal online maupun ofline. Data-data dikumpulkan untuk dianalisa apa yang menjadi inti dalam proses strategi pembelajaran berbasis masalah. Pembahasan dari hal-hal yang bersifat khusus menuju inti yang umum.

\section{Pembahasan}

Strategi dalam KBBI online mempunyai ragam arti. Diantara arti dapat dinyatakan sebagai rencana yang cermat mengenai kegiatan untuk mencapai sasaran khusus. rencana yang cermat berarti penuh pertimbangan. Aspek-aspek yang berkaitan dalam perencanaan dipertimbangkan secara detil. Rencana tersebut dikaitkan dengan tujuan yang sudah ditetapkan untuk mencapai kesuksesan. Hal-hal yang akan dilakukan dalam kegiatan disusun secara cermat dan penuh pertimbangan menuju tercapainya sasaran atau tujuan.

Pembelajaran menurut Degeng, 1989 adalah upaya membelajarkan siswa. siswa melaksanakan berbagai kegiatan untuk belajar suatu hal yang ditetapkan guru. Kegiatan-kegiatan disiapkan oleh guru dalam rangka mengupayakan siswa dalam proses belajar. Hamalik menjelaskan pembelajaran merupakan susunan atas gabungan beberapa aspek baik prosedur, fasilitas, perlengkapan dan material. Berbagai gabungan unsur tersebut mempunyai hubungan saling mempengaruhi. Berbagai pengaruh yang timbul dari unsur yang digabung, diarahkan untuk mencapai tujuan pembelajaran. Miftahul Huda (2013: 2) menambahkan pembelajaran adalah sesuatu yang diperoleh dari pengaruh memori, kognisi dan metakognisi terhadap pemahaman siswa dalam kondisi alami atau terencana.

Berbasis masalah dapat diartikan menggunakan atau memakai suatu permasalahan sebagai dasar. Suatu masalah dijadikan objek dan awal, materi kajian dalam kegiatan tertetntu. kata Masalah dalam KBBI online 
berarti sesuatu yang memerlukan penyelesaian. Suatu proses kegiatan terencana dengan menggunakan permasalahan sebagai asas pelaksanaan.

Made Wena (2019) menyatakan strategi belajar berbasis masalah merupakan strategi pembelajaran dengan menghadapkan siswa pada permasalahan-permasalahan praktis sebagai pijakan dalam belajar atau dengan kata lain siswa belajar melalui permasalahan-permasalahan. Proses pembelajaran dengan berpijak pada berbagai masalah yang ada dilingkungan terdekatnya. Dengan memilih suatu kasus tertentu kemudian dipakai untuk bahan kajian pembelajaran. diharapkan siswa belajar dari masalah yang ada untuk diambil hikmah dalam berperilaku. Aspek penting dalam menjadikan masalah sebagai kajian juga berkaitan dengan solusi yang dirumuskan untuk memecahkan masalah tersebut. Sehingga siswa juga mengetahui apa yang harus mereka lakukan dalam rangka ikut andil dalam menyelesaikan masalah. Boud dan Felleti (1997) Fogarty (1997) dalam (Made Wena, 2019) dijelaskan strategi pembelajaran berbasis masalah adalah siswa dikonfrontasikan pada masalah-masalah praktis yang dilakukannya atau oleh orang-orang sekitar. Konfrontasi yang dihadirkan kepada siswa dapat berupa analisa terbuka atau bahkan tidak terstruktur sekalipun. Lukman Hakim (2015: 40) menjelaskan siswa madrasah sejak dini perlu diberikan pengetahuan melalui pembelajaran berbasis masalah mengenai problem-problem yang dihadapi masyarakat dengan dibarengi berbagai macam penyelesaiannya.

Ada beberapa Karakteristik strategi pembelajaran berbasis masalah menurut Savoi dan Hughes diantaranya: Pertama suatu permasalahan yang dipilih dijadikan awal proses pembelajaran. Kedua permasalahan yang dikaji tentu terkait peristiwa yang terjadi di kalangan siswa. Ketiga Pembelajaran diorganisasikan dengan membahas di seputar aspek permasalahan mulai faktor penyebab sampai tujuan perilaku. Keempat Tanggung Jawab dalam menjalankan dan membentuk proses pembelajaran diberikan kepada siswa untuk memunculkan berbagai aspek dalam kasus. Kelima Proses diskusi dilakukan oleh setiap kelompok kecil yang dibuat dari anggota kelas. Keenam Hasil diskusi dipresentasikan siswa berbentuk produk dan kinerja setiap anggota kelompok dan aspek-aspek yang muncul ketika proses pengungkapan.

Karakteristik strategi pembelajaran berbasis masalah dimunculkan dalam proses pelaksanaanya. Berbagai tahap yang dilakukan dalam proses harus tersusun sesuai sistematika strategi. Tahap-tahap strategi pembelajaran berbasis masalah dapat memilih penjelasan menurut Fogarty (1997) yang meliputi: menemukan masalah, mendefinisikan masalah, 
mengumpulkan fakta, menyusun hipotesis, melakukan penyelidikan, menyempurnakan permasalahan yang telah didefinisikan, menyimpulkan alternatif pemecahan secara kolaboratif, dan melakukan pengujian hasil (solusi) pemecahan masalah.

Sementara Miftahul Huda (2013: 272) secara operasional Probem based learning dilakukan dengan pertama: siswa disajikan suatu masalah. Kedua: siswa mendiskusikan masalah sesuai tutorial dimasing-masing kelompok kecil. Dalam diskusi, siswa mengklarifikasi fakta-fakta suatu kasus dengan berdasar pada pengetahuan yg sudah dimiliki siswa. siswa mengklarifikasi proses urutan suatu masalah bisa terjadi dengan diawali kejadian apa, siapa pelakunya, dan bentuk perlakuan apa yang di lakukan dari pelaku maupun korban. Siswa mengidentifikasi sebab-sebab apa yang mengakibatkan masalah bisa terjadi. Siswa membuat rencana tindakan untuk menyelesaikan masalah.

Ketiga: siswa terlibat dalam kajian didalam kelompoknya bagaimana dilakukan penyelesaian masalah tersebut. penyelesaian masalah didasarkan pada acuan tindakan yang ada dalam perpusatakan, website, masyarakat, atau observasi. keempat: berdasar pengetahuan dari referensi perpustakaan, website atau masyarakat siswa melakukan sharing informasi dengan teman diskusinya atau kelompok lainnya untuk mencari pengetahuan baru atau melihat cara penyelesaian dari grup lain.

Kelima: kelompok mempresentasikan solusi atas masalah dan review atas apa yang sudah dipelajari. Anggota kelompok mengikuti kegiatan reviewberpasangan, maupun kelompok, atau review berdasarkan bimbingan guru. Masing masing siswa melakukan refleksi atas kontribusinya terhadap proses pembelajaran berbasis masalah.

Dari kegiatan pelaksanaan strategi pembelajaran berbasis masalah diaharapkan siswa mempunyai respek terhadap lingkungan mereka. Permasalahan-permasalahan yang terjadi di lingkungan terdekat maupun yang dialami teman mereka dapat diambil pelajaran bagi siswa. dengan kesadaran akan masalah yang dialami temannya siswa dapat mengantisipasi dan berusaha menyelesaikan masalah nya sendiri maupun bantuan solusi kepada orang-orang dilingkungannya.

Penerapan strategi pembelajaran berbasis masalah di dalam kelas dari langkah-langkah menurut forgarty dapat dilakukan kegiatan sebagai berikut:

1. Setelah guru melakukan kegiatan pra pembelejaran, guru memberitahukan kejadian-kejadian masalah yang terjadi dilingkungan siswa atau kejadian yang barusaja terjadi. Masalah yang terjadi yang 
sudah umum diketahui oleh siswa dan menjadi perbincangan siswa contoh perkelahian siswa a dengan siswa b. Siswa diberi pertanyaan apakah mengetahui kejadian tersebut. atau bahkan mengetahui secara detail peristiwa dari awal sampai akhir. Guru memberikan beberapa fakta awal tentang terjadinya masalah. Siswa juga diberi kesempatan untuk mencari informasi terkait adanya permasalahan tersebut. (1.tahap menemukan masalah)

2. Guru memberikan tugas dan kesempatan kepada siswa untuk mendefinisikan dan menilai apakah permasalahan yang terjadi merupakan kebaikan atau keburukan, menguntungkan atau merugikan, bertanggung jawab atau tidak bertanggungjawab dst. Guru membimbing siswa untuk memperkirakan aspek atau hal yang berkaitan dengan permasalahan tersebut contoh apa yang melatar belakangi terjadinya pertengkaran, apa yang mendorong terjadinya permasalahan tersebut. bagaimana permasalahan pertengkaran saat itu bisa terhenti. Dukungan apa yang memperparah adanya masalah tersebut yang dilakukan korban maupun pelaku. Siswa didorong untuk mengungkap semua hal yang berkaitan dengan terjadinya peristiwa tersebut. (2. Mendefinisikan masalah)

3. Berdasarkan berbagai aspek yang sudah diungkap dan dicatat siswa, guru memberika tugas untuk mengumpulkan fakta-fakta pertengkaran berdasarkan / mengacu pada hasil definisi dan pencarian aspek-aspek yang berada apada kesatuan masalah. Guru memberikan contoh, semisal dari aspek sebab, siswa diminta mengumpulkan sebab-sebab apa saja yang mendorong pelaku pertengkaran melakukan masalah tersebut. faktor-faktor apa yang mendukung terjadinya konflik siswa dll. Pada langkah ini siswa bertugas mencari sebanyak mungkin data-data lapangan yang berkaitan dengan peristiwa konflik/ perkelahian. Siswa juga berbagi dengan teman belajarnya tentang apa saja yang harus dikumpulkan fakta-fakta permasalahan yang terjadi. Guru memberikan bimbingan bagaimana metode yang dipakai siswa dalam mengumpulkan data. Siswa dibimbing untuk menggali data dari sumber yang melihat kejadian perkelahian berlangsung. Informasi-informasi yang dicari berdasar beberapa aspek. Aspek itu diantaranya informasi apa yang diketahui oleh sumber yang mengetahui terjadinya peristiwa perkelahian. informasi apa saja yang dibutuhkan untuk mengunggkap peristiwa perkelahian. siswa juga dibimbing terkait apa yang akan dilakukan terhadap informasi yang ada. (3.mengumpulkan fakta) 
4. Guru memberikan arahan kepada siswa untuk merumuskan jawaban sementara/perkiraan logis terhadap jawaban masalah. Dalam memperkirakan jawabab masalah, siswa membuat hubungan-hubungan antar berbagai fakta yang ditemukan. Dugaan dugaan terkait penyebab dan dorongan pelaku melakukan perkelahian. penyebab utama perkelahian berdasar fakta. Pelaku utama dan kesalahan awal yang dilakukan. Serta korban apakah melakukan kesalahan kepada pelaku atau sebaliknya. Siswa juga diberi tugas untuk memperkirakan jawaban sementara yang bermacam-macam. Sehingga berdasarkan data sementara jawaban mana saja yang mungkin benar. Hal ini perlu dimunculkan berbagai perkiraan jawaban yang banyak. Jawaban yang bermacam-macam tentu bukan kesimpulan yang final/akhir tetapi perlu dibuktikan lagi melalui proses selanjutnya. (4. Menyusun Hipotesis)

5. Guru membimbing siswa untuk melakukan penyelidikan tentang info yang sudah diperolehnya apakah benar-benar terjadi ataukah hanya sangkaan. Berbagai info yang terkumpul diselidiki kebenaran datanya dengan mengkonfirmasi kepada pelaku maupun korban. Penyelidikan kebenaran data juga diselidiki melalui orang lain yang mengetahui proses kejadian. Siswa bertanya kepada orang-orang mengetahui detail kejadian pertengkaran. Guru merumuskan dan merencanakan langkahlangkah pembelajaran yang dapat digunakan siswa untuk memahami permasalahan serta memahami lingkungannya. Siswa berupaya mencari lebih dalam makna dari peristiwa dan kebenaran data yang diperoleh setelah dilakukan penyelidikan. (5.Melakukan Penyelidikan)

6. Berdasar fakta yang benar, guru membimbing siswa untuk menyempurnakan inti permasalahan/pertengkaran siswa. apakah dengan terungkapnya kebenaran data permasalahan perlu diperbaiki atau memang sudah sesuai dengan dugaan. Apabila fakta menunjukkan perubahan pelaku atau korban ata ada orang lain yang menjadi pokok pertengkaran. Dengan begitu maka permasalahn yang sebenarnya dapat ditetapkan secara teliti dan cermat.

7. Ketika permasalahan yang sebenarya mulai jelas, berdasarkan faktafakta maka guru membimbing siswa untuk dilakukan dan dirumuskan berbagai langkah untuk menyelesaikan permasalahan tersebut. penyelesaian masalah di rumuskan dengan bentuk yang bermacammacam sesuai dengan faktor-faktor penyeban. Solusi juga dibuat bersama untuk menyelesaikan masalah berdasar apek-aspek pendukung yang terdapat dalam peristiwa perkelahian. 
8. Ketika siswa sudah membuat berbagai solusi/ pilihan pemecahan masalah, maka guru membimbing siswa untuk melakukan percobaan untuk dilakukan praktik pemecahan masalah. Siswa didampingi guru melakukan pengujian solusi apakah mempunyai efek yang diharapkan atau tidak. Dengan dilakukan praktik pengujian solusi diharapkan siswa mampu menemukan arti dari aktifitas kebaikan. Siswa menemukan arti pentingnya perilaku kebaikan dan pengarunya terhadap orang lain melalui uji coba solusi.

\section{Kesimpulan}

Strategi pembelajaran belajar berbasis masalah sebagai salah satu langkah pembelajaran yang strategis dalam upaya pencegahan terhadap perilaku penyimpangan sosial (perkelahian siswa). Strategi ini menghadapkan siswa secara langsung baik dalam bentuk angan-angan atau berfikir kongkrit tentang permasalahan kehidupan secara praktis sebagai pijakan dalam kegiatan pembelajaran. Pada intinya strategi pembelajaran berbasis masalah sangat responsif terhadap lingkungan sekitar.

Beberapa langkah-langkah dalam menjalankannya melupiti: display masalah, penilaian oleh siswa, penugasan, arahan jawaban sementara, penyelidikan, penyempurnaan, perumusan langkah penyelesaian masalah, dan uji coba atas solusi penyelesaian masalah.

\section{Daftar Rujukan}

Huda, Miftahul. 2013. Model-Model Pengajaran dan Pembelajaran: isu-isu metodeis dan paradigmatis. Yogyakarta: Pustaka Pelajar.

Hartono, Izi. 2019 https://jatim.tribunnews.com diunduh pada 2-10-2019 pukul $10.00 \mathrm{WIB}$

Sanjaya, Wina. 2007. Strategi Pembelajaran Berorientasi Standar Proses Pendidikan. Jakarta:Kencana Prenada Media Group.

Wena, Made. 2014. Strategi Pembelajaran Inovatif Kontemporer: suatu tinjauan konseptual operasional. Jakarta: Bumi Aksara.

Zulkifli dan Royes, Nadjamuddin. 2017. JIP: Jurnal Ilmiah PGMI Volume 3, Nomor 2, Desember.

Hakim, Lukman. 2015. Jurnal Pendidikan Islam. Ta'lim. Vol 13. No. 1. 